UCRL-ID-126999 Rev A

\title{
National Ignition Facility System Design Requirements Conventional Facilities SDR001
}

J. Hands

April 9, 1996

This is an informal report intended primarily for internal or limited external distribution. The opinions and conclucions stated are those of the author and may or may not be those of the Laboratory.

Work performed under the auppices of the U.S. Department of Energy by the Lawrence Livermore National Laboratory under Contract W-7405-Eng-48. 


\section{DISCLAIMER}

This document was prepared as an account of work sponsored by an agency of the United States Government. Neither the United States Government nor the University of California nor any of their employees, makes any warranty, express or implied, or assumes any legal liability or responsibility for the accuracy, completeness, or usefulness of any information, apparatus, product, or process disclosed, or represents that its use would not infringe privately owned rights. Reference herein to any specific commercial product, process, or service by trade name, trademark, manufacturer, or otherwise, does not necessarily constitute or imply its endorsement, recommendation, or favoring by the United States Government or the University of California. The views and opinions of authors expressed herein do not necessarily state or reflect those of the United States Government or the University of California, and shall not be used for advertising or product endorsement purposes.

This report has been reproduced directly from the best available copy.

Available to DOE and DOE contractors from the Office of Scientific and Technical Information

P.O. Box 62, Oak Ridge, TN 37831

Prices available from (615) 576-8401, FTS 626-8401

Available to the public from the

National Technical Information Service

U.S. Department of Commerce

5285 Port Royal Rd.,

Springfield, VA 22161 
NIF-96-226

L-21705-01

WBS 1.2

\section{National Ignition Facility}

\section{System Design Requirements}

Conventional Facilities

SDR001

Revision A

April 9, 1996

Prepared by:

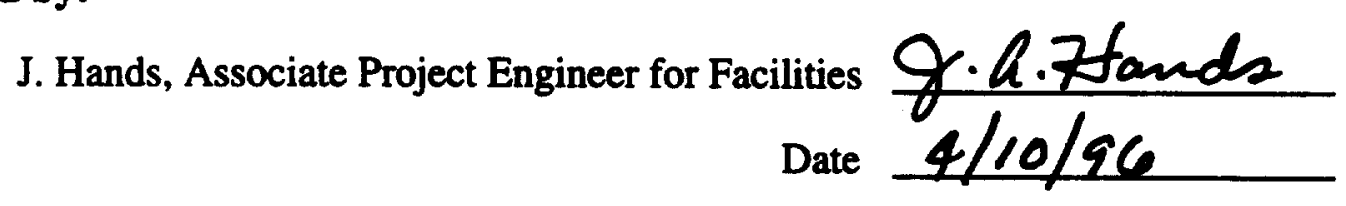

Engineering Review Board Approval:

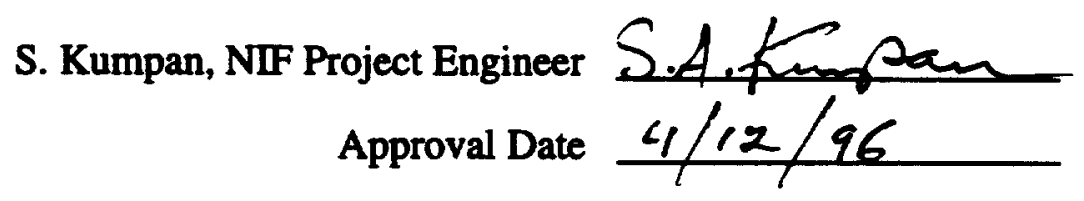

Level 3 Change Control Board Approval:

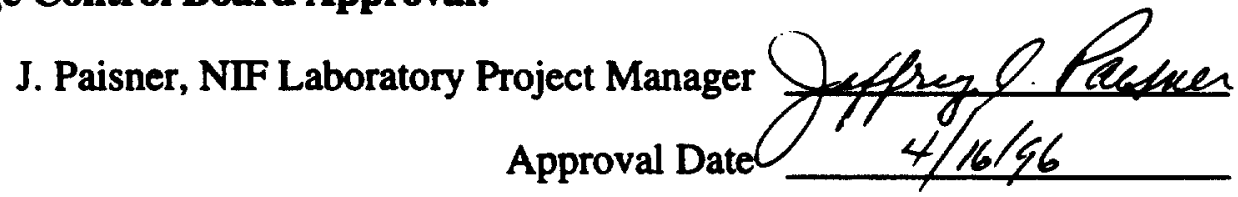




\section{Paragraph}

1.

1.01 .

1.02 .

1.02 .01 .

1.02 .02 .

1.02 .03 .

2.

2.01 .

2.02 .

2.03 .

2.03.01.

2.03.01.01.

2.03.01.02.

2.03.01.03.

2.03.02.

2.03.02.01.

2.03.02.01.01.

2.03.02.01.01.01.

2.03.02.01.01.02.

2.03.02.01.01.03.

2.03.02.01.01.04

2.03.02.01.01.05.

2.03.02.01.01.05.01.

2.03.02.01.02.

2.03.02.01.02.01.

2.03.02.01.02.02.

2.03.02.01.03.

2.03.02.01.04.

2.03.02.01.05.

2.03.02.03.

2.03.03.

2.03.03.01.

2.03.03.02.

2.03.03.03.

2.03.03.04.

2.03.03.05.

2.03.03.06.

2.03.03.07.

2.03.03.08.

2.03.03.09.

2.03.03.10.

2.03.03.11.

3.

3.01 .

3.01 .01 .

3.02 .

\section{Title}

Introduction

Mission

Scope

Requirements Heirarchy

Definitions

Revising SDR

System Definition

System Description

System Interfaces

Major Subsystems

Site Improvements

Secure Perimeter

Roads, Parking and Walkways

Utilities, Sewage and Drainage

Experimental Facilities

Laser and Target Area Building (LTAB)

Laser Building

Laser Bays

Capacitor Banks

Operations Support Area

Visitor Facilities

Mechanical Equipment

Mechanical Equipment Bay

Target Area Building

Target Bay

Switchyards

Target Diagnostics Building

Environmental Control

Clean Areas

Optics Assembly Building

Support Facilities

Office Building

Target Receiving and Inspection Building

General Assembly Building

Electro-Mechanical Shop

Warchouse (General Storage)

Shipping, Receiving and General Stores

Medical Facility

Cafeteria

Garage and Gas Station

Fire Station

Security and Badging

System Design Requirements

Applicability to Site

Updating Requirements after Site Selection

Design Lifetime 


\section{Table of Contents}

\section{Paragraph}

3.02.01.

3.02 .02 .

3.02.03.

3.02.03.01.

3.02.03.02.

3.02.03.03.

3.03 .

3.03.01.

3.03.02.

3.03.02.01

3.03.02.01.01.

3.03.02.01.02.

3.03.02.01.02.01.

3.03.02.01.02.02.

3.03.02.02

3.03.02.02.1

3.03.02.02.2

3.03.02.03.

3.03.02.04.

3.03.02.05.

3.03.02.06.

3.03.02.07.

3.03.02.08.

3.03.02.09.

3.03.03.

3.03.03.01.

3.03.03.02

3.03.03.02.01.

3.03.03.02.02.

3.03.03.02.03.

3.03.03.02.04

3.03.03.02.05

3.04 .

3.04.01.

3.04.02.

3.04.02.01

3.04 .02 .01 .1

3.04.02.02.

3.04.02.02.01.

3.04.02.02.02.

3.04.03.

3.04.03.01.

3.04.03.01.01.

3.04.03.01.02.

3.04.03.01.07.01.

3.04.03.02.

\section{Title}

Ease of Replacement

Design Life of Existing Facilities

Facility Survival

Performance Class

Probability of Natural Phenomena

Seismic Analysis

Operations

Personnel

Operational Availability

Reliability, Availability and Maintenance

Reliability

Inherent Availability

Spare Equipment

Maintenance Equipment

Maintainability

Maintenence Time Goal

Maintainability Features

Annual Shot Rate

Increased Shot Rate

Annual Number of Yield Shots

Total Annual Yield and Source Team

Time Between No-yield Shots

Laser Shot Accuracy

Recovery from Abnormal Events

Classified Operations

Changing Between Classification Levels

Safeguards and Security

Establishment of Security Requirements

Security - Limited Areas

Automated Data Processing Security

Security Plan

Protection of Property and Facilities

Environmental Protection and Health Safety

Siting

Waste and Effluents

Liquid Effluents

Target Bay Liquid Effluents

Airborne Effluents

Elevated Exhaust Release Point

Monitoring of Exhaust Air

Radiation Protection

Maximum Credible Yield

Waste Handling Area Confinement and Ventilation

Waste Collection and Processing

Negative Pressure Ventilation

Radiation Protection of the Public 


\section{Table of Contents}

\section{Paragraph}

3.04.03.02.01.

3.04.03.02.02.

3.04.03.03.

3.04.03.04.

3.04.03.05.

3.04.03.05.01.

3.04.03.06.

3.04.03.07

3.04.03.08.

3.04.04.

3.04.04.01.

3.04.04.01.01.

3.04.04.02.

3.04.05.

3.04.05.01.

3.04.05.02.

3.04.05.02.01.

3.04.05.02.02.

3.04.05.02.03.

3.04.05.02.04.

3.04.05.02.05.

3.04.05.02.06

3.04.05.03.

3.04.05.03.01.

3.04.05.03.02.

3.04.05.03.03.

3.04.05.03.04.

3.04.05.03.05.

3.04.05.03.06.

3.04.05.03.07.

3.05 .

3.05.01.

3.05.02.

3.05.03.

3.05.04.

3.05.05.

3.06 .

3.06.01.

3.06.02.

3.06.03.

3.06.04.

3.06.05.

3.07

3.08 .

3.09 .

3.12 .
Title

Public Exposure to Airborne Radionuclides

Public Exposure from all Sources

Radiation Protection of NIF Personnel

ALARA Principle

Radiation Shielding

Concrete Shielding

Radiation Monitoring of Switchyards, Target Bay and Target Chamber

Tritium Confinement

Compliance with Radiological Safety Requirements

Decontamination and Decommissioning

Target Chamber Cleaning

Target chamber interior decontamination

Design for Decommissioning

General Safety

Low-Hazard Radiological Facility

Life Safety

Egress Features

Laser Safety

Industrial Hygiene and Occupational Safety

Construction Safety

Default to Safe State Upon Loss of Power

Facility Safety Interlocks

Fire Protection Program

Fire Protection - Structural Members

Fire Barriers

Improved Risk Fire Protection

Automatic Fire Sprinklers

Ancillary Fire-Protection Systems

Fire Loss (Maximum Allowable)

Fire Loss (Maximum Credible)

Electrical Power

Voltage Quality

Low Voltage Protection of Computers

Standby Power

Power for Safety and Security Functions

Standby Power for Operations

Future Modifications and Upgrades

Design and Construction Tradeoffs

Accommodating Range of Needs

Potential Upgrade to Direct-drive

Radiation Effects Testing Capability

Future Additional Target Chamber

General Design Criteria

Documentation

Quality Assurance Program

Experimental Facilities 


\section{Paragraph}

3.12.01.

3.12.01.02.

3.12 .01 .02 .01 .

3.12.01.02.02.

3.12.01.02.03.

3.12.01.03.

3.12.01.03.A

3.12.01.03.01.

3.12.01.03.01.01.

3.12.01.03.01.01.01.

3.12.01.03.02.

3.12.01.04.

3.12.01.04.01.

3.12.01.04.02.

3.12.01.04.03.

3.12.01.04.04.

3.12.01.04.05.

3.12.01.05.

3.12.01.05.01.

3.12.01.05.01.1

3.12.01.05.01.2

3.12.01.05.02.

3.12.01.05.03.

3.12.01.05.03.A

3.12.01.06.

3.12.01.06.A

3.12.01.07.

3.12.01.08.

3.12.01.09.

3.12.02.

3.12.02.01.

3.12.02.02.

3.12.02.02.01.

3.13.

3.13.02.

3.13.03.

3.13.04.

3.13.05.

3.13.06.

3.13.07.

3.13.08.

3.13.09.

3.13.10.

3.13.11.

3.13.12.

4.

\section{Title}

Laser and Target Area Building

Laser Building

Laser Bays

Capacitor Banks

Operations Support Area

Target Area Building

Diagnostic Removal and Replacement

Target Bay

Target Bay Cryogenics

User-supplied Cryostats

Switchyards

Diagnostics Building

Diagnostics Operations and Support

Decontamination Area

Environmental Protection System

Target Receiving and Installation

Tank Farm

Environmental Control

Vibration and Acoustic Noise

Specific LTAB Vibration Constraints

Foundation Decoupling

Floor Deflection

Temperature and Humidity

Specific LTAB Temperature Constraints

Clean Areas

Specific LTAB Cleanliness Constraints

Electrical Supply and Grounding Systems

Mechanical Equipment

Visitor Facilities

Optics Assembly Building

Internal Environment

Clean Rooms

Cleaning Methods

Support Facilities

Office Building

Target Receiving and Inspection Building

General Assembly Building

Electrical / Mechanical Shop

Warehouse

Shipping, Receiving, and Central Stores

Medical Facility

Cafeteria

Garage and Gas Station

Fire station

Security and Badging

Applicable Documents 


\section{Table of Contents}

NIF - SDR001 - Conventional Facilities Systems Design Requirements

\section{Paragraph}

4.01 .

4.02 .

4.02 .01 .

4.02.02.

4.02.03.

4.03 .

4.03.01.

4.03.02.

4.04 .

4.05 .

4.06 .

4.07 .

5.

\section{Title}

Freezing of Orders

Compliance with DOE Orders and Federal Regulations

Exceptions to DOE Orders

List of Applicable DOE Orders

Partial List of Applicable Federal Regulations

Codes and Standards

Updating List of Codes and Standards

List of Applicable National Consensus Codes and Standards

State and Local (County, City, etc.) Requirements

Applicable LLNL Standards

Applicable NIF Project Documents

Applicable NIF Drawings

Acronyms 


\section{1 .Introduction}

NIF Project Control Procedure 6.1 (Preparation and Revision of System Design Requirements; NIF-LLNL-93-251, L-16551-2) establishes the methods and responsibilities for identifying, preparing, approving, and revising the NIF System Design Requirements (SDRs).

SDRs contain verifiable engineering design requirements that flow down from higher level NIF requirements, DOE orders, and other applicable codes, standards and regulations.

\subsection{Mission}

The National Ignition Facility (NIF) will be a key element in the Department of Energy's Defense Programs aboveground experimental (AGEX) capabilities for maintaining nuclear competence and weapons effects simulation. The primary mission of the NIF Project will be to demonstrate fusion ignition in the laboratory. The most immediate application of the NIF will be to provide nuclear-weapon-related physics data, since many phenomena occurring on the laboratory scale are similar and relevant to those occurring in weapons. The NIF may also provide an important capability for weapons effects simulation. The second purpose for the NIF is to achieve propagating fusion burn and modest energy gain for development as a soucre of civilian energy, as stated in the NIF Justification of Mission Need which was endorsed by the Secretary of Energy, the DOE's Fusion Policy Advisory Committee, and the National Academy of Sciences Inertial Fusion Review Group.

The following are the potential sites for the NIF:

Lawrence Livermore National Laboratory,

Los Alamos National Laboratory, Sandia National Laboratory/New Mexico, Nevada Test Site, North Las Vegas.

\subsection{Scope}

This System Design Requirements (SDR) document specifies the functions to be performed and the minimum design requirements for the National Ignition Facility (NIF) site infrastructure and conventional facilities. These consist of the physical site and buildings necessary to house the laser, target chamber, target preparation areas, optics support, and ancillary funtions.

The site and buildings described in this SDR are generic in nature and are not site-specific. Rather, they are the minimum facilities needed to support the NIF activities. Even though the actual NIF site may contain a mixture of new and existing facilities, this SDR will address all of the requirements as new facilities. There will be some instances such as seismic requirements in which specific critieria have been selected to allow for consistent facility description and cost estimating.

The conventional facilities element of the WBS provides the buildings and site infrastructure for the NIF Project. These buildings house the laser system and the target area as well as the additional facilities necessary to support operation and maintenance activities. These additional facilities include subsystem assembly areas, optics refurbishment facilities, machine shops, target receiving and inspection facilities, office space, and other general-use space necessary to support the project staff during both construction and operation. Site infrastructure must provide electric power, communication, water, sewage, and cooling services for all project facilities. Standard building utilities will be distributed for convenient access to project special equipment areas. These utilities include the standard services plus monitoring systems, environmental control, and safeguards and security systems. 


\subsubsection{Requirements Heirarchy}

There are four levels of design requirements for the NIF project:

Level 1: Primary Criteria;

Level 2: Functional Requirements;

Level 3: System Design Requirements;

Level 4: Interface Control Documents and other requirements.

Each criteria level is consistent with the requirements of the next higher (lower numbered) level criteria. Level 1 and 2 requirements establish the fundamental performance and design objectives for the NIF project. They flow down to the System Design Requirements documents which comprise the Level 3 requirements. Each requirement within an SDR is traceable to one or more higher level requirements or a requirement in another SDR.

There are five SDRs:

SDR 001 Conventional Facilities

SDR 002

SDR 003

SDR 004

SDR 005
Laser System

Target Area Integrated Computer Controls Optics
WBS 1.2

WBS $1.3,1.4,1.6,1.7,1.8$

WBS 1.8

WBS 1.5

WBS 1.6

There are four Subsystem Design Requirements (SSDRs) under SDR001:

SSDR 1.1

SSDR 1.2

SSDR 1.3

SSDR 1.4
Site Improvements

Laser and Target Area Building (LTAB)

Optics Assembly BUilding (OAB)

Support Facilities
WBS 1.2.1

WBS 1.2.2.1

WBS 1.2 .2 .3

WBS 1.2.3 


\subsubsection{Definitions}

\section{Parent Req't:}

The paragraph number(s) in the Functional Requirements and Primary Criteria from which the requirement in the present document is derived. Requirements may have multiple parents. It is useful to identify the important parents in order to be able to determine what lower requirements are affected by a change at a higher level.

\section{Supporting Document:}

A supporting document such as an analysis which may be needed to generate the present requirement from the parent requirement. For example: a staffing study to determine the number of personnel required. Not all requirements have Supporting Documents.

\section{Related Req't:}

Other SDRs which either affect the requirement or are affected by the requirement.

Owner:

The project member who is responsible for assuring that the requirement is accurate and for verification that the project satisfies the requirement.

\section{Verification:}

How the project will show that the requirement has been met or exceeded.

Applies to:

The types of systems which are primarily affected by the requirement. (Performance; Optics;

Mechanical; Electrical; Instrumentation and Control; Reliability, Availability and Maintainability; Environmental Safety and Health; Target Physics; and Other (specify in Comments).

Shall:

This denotes a requirement that is mandatory and must be met.

Should:

This denotes a non-mandatory recommendation or goal.

\subsubsection{Revising SDR}

SDRs are controlled by the Level 3 Change Control Board and the NIF Project Manager. The process for changing or revising SDRs is defined by NIF Project Control Procedure 6.1: Preparation and Revision of System Design Requirements (NIF-LLNL-93-251, L-16551-2). 


\section{System Definition}

The NIF site includes a centrally located experimental facility (LTAB and OAB) and multiple supporting facilities. This Conventional Facility SDR document contains the design requirements for all of these facilities and the site improvements necessary to accommodate them.

The conventional facility subsystem provides

1) All site infrastructure, including roadways, parking, and pathways, and

2) Utilities to support operations, such as sanitary sewers, storm drains, potable water, cooling water, natural gas and compressed air, and distributed electrical/communication systems.

3) Experimental facilities housing target and laser operations and providing areas for diagnostics, a control room, hazardous packaging, decontamination, maintenance, capacitor banks, and tritium recovery. For the purpose of this SDR, the special optics processing facilities are also categorized as experimental facilities.

4) Supporting facilities providing sufficient area to accommodate offices, target receiving and inspection, general assembly, electrical/mechanical assembly and fabrication, warehousing, shipping, receiving and inspection, medical facilities, a cafeteria, garage and gas station, fire station, and security and badging.

The SDRs identify space requirements, environmental conditions (temperature, humidity, cleanliness, etc.) lighting, electrical, and other special requirements needed by these areas. 


\subsection{System Description}

NIF is projected to occupy approximately $0.20 \mathrm{sq}-\mathrm{km}$. A representative layout of the anticipated functional areas is shown below.

The NIF experimental facilities will include the Laser and Target Area Building (LAB) and the Optics Assembly Building (OAB).

In addition to the experimental facilities, the NIF requires site infrastructure and support facilities including:

Site-wide utilities such as process cooling, electrical power, storm drains, sewers, etc. Offices.

Target receiving and inspection.

Component and system assembly areas.

Storage.

Site services such as medical, fire protection, cafeteria, security, etc.

Other conventional infrastructure such as roads, parking, walkways, secure perimeter, etc.

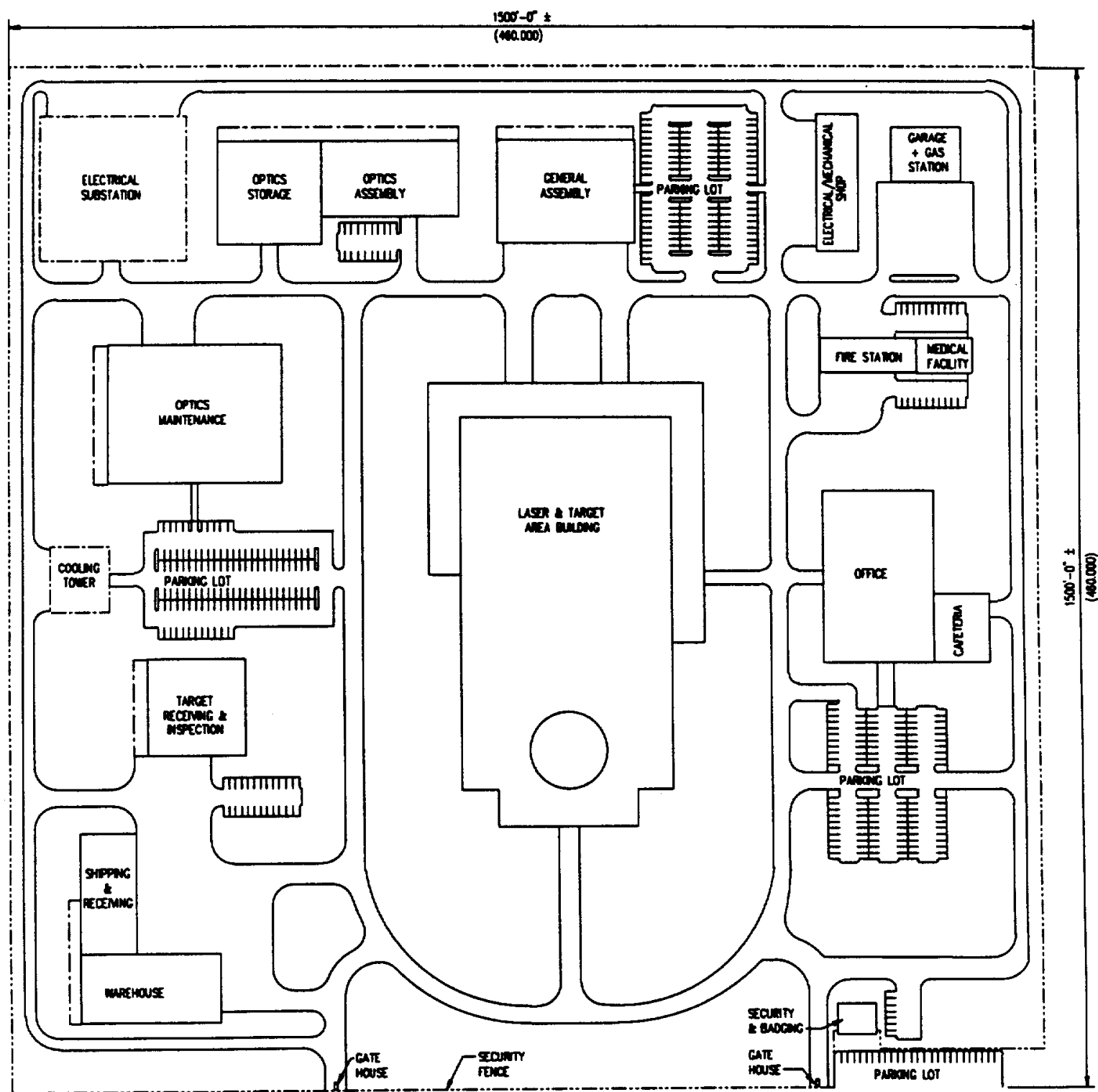

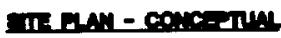


2orufiam

Fig 5.1-1 (240)

\subsection{System Interfaces}

The Conventional Facilities will have the following interfaces with the NIF site:

Electrical power,

Fire water,

Potable water,

Cooling tower water,

Sanitary sewer,

Storm drainage,

Process gas,

Security systems,

Emergency systems, and

Hazardous waste management.

The LTAB will interface with the following special equipment:

Laser (SDR 002)

Laser Structures (WBS 1.4.3)

Laser Alignment Systems (WBS 1.7.1)

Amplifier Power Conditioning (WBS 1.3.4)

Pockels Cell (WBS 1.3.3)

Spatial Filters (WBS 1.4.1)

Final Optics (WBS 1.8.7)

Beam Diagnostics (WBS 1.7.2)

Target Area (SDR 003)

Target Area Structures (WBS 1.8.4)

Target Diagnostics (WBS 1.8.3)

- Environmental Protection Systems (WBS 1.8.5)

Target Area Auxiliary Systems (WBS 1.8.6)

Integrated Computer Controls Systems (SDR 004)

- Horizontal and vertical mounts for the Target Chamber,

Optical component mountings,

Electrical supplies and grounding,

Capacitor bank power supplies,

Diagnostics,

Environmental Protection System.

The OAB will interface with the following special equipment:

Laser (SDR 002)

Pockels Cell (WBS 1.3.3)

Spatial Filters (WBS 1.4.1)

Final Optics (WBS 1.8.7)

Optics (SDR 005) 


\subsection{Major Subsystems}

The Conventional Facilities include:

Site Improvements

Secure Perimeter

Roads, Parking and Walkways

Utilities, Sewage and Drainage

Experimental Facilities

Laser and Target Area Building (LTAB)

Optics Assembly Building (OAB)

Support Facilities

Office Building

Target Receiving and Inspection Building

General Assembly Building

Electro-Mechanical Shop

Warehouse (General Storage)

Shipping, Receiving and General Stores

Medical Facility

Cafeteria

Gas Station and Garage

Fire Station

Security and Badging

\subsubsection{Site Improvements}

The site improvements provide for all of the following functions:

Site grading and landscaping;

Roads, parking and walkways for NIF facilities;

NIF-specific mechanical infrastructure:

sanitary sewage,

storm drains,

potable water,

process cooling water,

heating fuel;

NIF-specific electrical distribution and communication systems:

high voltage distribution,

area substations,

telephone system,

computer networks for classified and unclassified data, site lighting for roads, parking and pathways.

\subsubsection{Secure Perimeter}

The NIF site will have security features, including a secure perimeter, to meet the requirements for physical protection, protection of vital equipment, and classified equipment and information according to the requirements in this SDR.

Site access/egress will be at two points, both gated and guarded, with one entry/exit being the primary contact with the LTAB facility and containing badging as well as security functions. The other entry/exit is provided for material deliveries.

A significant portion of the NIF site will be considered an open area; visitors to these areas will be required to enter through the badge office where they will be assigned a badge for access. 


\subsubsection{Roads, Parking and Walkways}

Site planning principles include separation of vehicular and pedestrian traffic, use of service roads to minimize cross traffic, and separate employee/visitor and service entrances to the site. All roads and service areas should be designed with sufficient turning radii to accommodate the large trucks accessing loading docks and service entrances at each facility.

Designated employee parking lots should be strategically located throughout the site. Location should be based on building occupancy, proximity to the workplace and functional requirements. Each parking lot should have clear access to a pedestrian path system efficiently directing individuals to their work areas. Visitor parking that is separate from employee parking lots will be landscaped with trees and shrubs to complement the architecture, present an appropriate public image to visitors, and provide a pleasing and productive work environment.

Main access roads serving the LTAB and the stores and warehouse buildings should be designed for heavy highway truck loads, such as liquid nitrogen delivery. The balance of the road and traffic system should be designed for standard trucks. The roadway system should include a perimeter road for both security and enhanced traffic flow.

The main employee and visitor parking areas are located near the office building and the technical support facilities. The visitor entrance will be through the security and badging facility where parking and access to the office building and LTAB is provided. The site has parking stalls for 420 vehicles distributed throughout the area. Handicapped, visitor, and government vehicle parking is provided and will be identified.

\subsubsection{Utilities, Sewage and Drainage}

The sewage system will be comprised of gravity service lines to feed to the host site system. No treatment facilities are contemplated as a part of the NIF site.

The site will also include storm drainage. The generic site is considered to have a $1-1 / 2 \%$ fall from one side to the opposite side where connections will be made to the host site system. The storm drainage system provides curb inlets or catch basins along all roadways and for all parking lots. Roof drains will connect to the storm drainage system.

\subsubsection{Experimental Facilities}

The experimental facilities consist of the Laser and Target Area Building (LTAB), the Optics Assembly Building (OAB), and the Diagnostics Building. 


\subsubsection{Laser and Target Area Building (LTAB)}

The LTAB is the major structure of the NIF complex which contains the experimental hardware, control systems, and diagnostics.

The Laser and Target Area Building consists of three main parts: the Laser Building (WBS 1.2.2.1), the Target Area Building (WBS 1.2.2.2), and the Diagnostics Building.

The LTAB will provide a thermally and vibrationally stable environment.

The conventional portions of the LTAB can be categorized as follows:

Foundation,

Structure,

Superstructure,

Enclosure,

Interior Finishes, and

Special Mechanical and Electrical Equipment and Construction.

The primary design requirements on the foundation, structure, and superstructure are to reduce vibration as much as possible and to survive the specified seismic events.

The enclosure will be selected to meet the environmental conditions at the selected site and to provide an aesthetically pleasing appearance for the life of the facility. Exterior walls will withstand the ambient environment, including wind loads.

The interior finishes will provide an aesthetic, functional and safe surrounding for the staff and visitors. Many of the interior walls will be fire rated to meet the fire protection requirements. Some of the walls will have sound transmission requirements.

The building will include clean areas, decontamination and waste processing equipment, HVAC equipment which will provide a thermally-stable and pressure-controlled environment, and material handling equipment including bridge cranes and elevators. Portions of the structure will meet requirements for confinement of ionizing radiation and emissions. The building also has special electrical supply and grounding requirements and requirements related to electromagnetic interference. Vibration isolation will be provided for all motors/generators and transformers rated at more than 100 kVA.

The LTAB will include:

Fire detection and alarm system,

Evacuation voice alarm system,

Telephone and computer networking system, and

Intrusion detection system.

There will be safety interlocks on:

Master Oscillator Room,

Capacitor rooms,

Laser Bays,

Target Room,

Optical Switchyard, and

any other areas where hazardous laser energy or extremely hazardous electrical energy may be present.

Access control will be provided on the above mentioned areas and the Classified Control Room.

The LTAB will be an "industrial" occupancy as defined in NFPA 101-LSC (Life Safety Code). The Uniform Building Code occupancy classification for the LTAB is primarily Group B (Laboratories - 
Testing and Research). Construction will be Type II per NFPA 220.

Because of the high value of the LTAB equipment, the building will incorporate features to limit the total potential fire loss to the monetary limits in the Fire Protection section of this SDR.

\subsection{Laser Building}

The Laser Building houses the laser system from the capacitors which power the laser to the spatial filter. The capacitors are located in four bays, the laser is located in two bays.

The building also houses the Operations Support Area (which contains the control rooms, the Master Oscillator Room, etc.), mechanical equipment (such as HVAC), and visitor facilities.

\subsection{Laser Bays}

Each Laser Bay houses half of the total number of laser beams, beginning with the Preamplifier Modules and extending to and including the Transport Spatial Filters. The portions of the laser beams prior to the Preamplifier Modules (i.e., the initial portions of the Optical Pulse Generation system) are located in the Master Oscillator Room in the Operations Support Area. The portions of the laser beam after the Transport Spatial Filters are located in the Target Building.

The Laser Bays provide a controlled and stable environment for the laser. The laser requires precise thermal and vibration control and a clean environment.

\subsection{Capacitor Banks}

The laser amplifiers are powered by large capacitors which are located in four banks. Each of the banks is located near the amplifiers to reduce the length of the electrical transmission line between the capacitor and the amplifiers.

The walls of the capacitor banks provide mechanical shielding to contain any projectiles which may be produced should a capacitor explode.

The banks are located on ground level to provide access for removal and replacement of the capacitors.

The capacitor banks are not clean areas.

\subsection{Operations Support Area}

The Operations Support Area contains:

Control Room

Classified Control and Data Room

Master Oscillator Room

Operations Planning Room

Computer Room

LTAB Offices

Document Library

Conference Room

Security System Area

Technical Maintenance Areas

Restrooms

Custodial Room 


\subsection{Visitor Facilities}

Areas will be provided to allow visitors to view a Laser Bay, a Switchyard, and the interior of the Target Bay.

\subsection{Mechanical Equipment}

The Laser Building includes the following types of mechanical equipment:

Elevators for personnel and equipment

Bridge cranes in the laser bays

Compressed gas and liquified nitrogen systems

Cooling water system

Vacuum systems

HVAC systems

Vibration isolation features

\subsection{01. Mechanical Equipment Bay}

The Laser Building HVAC systems will be housed in a mechanical equipment bay which will be vibrationally isolated from the Laser Bay slab.

\subsection{Target Area Building}

The Target Area Building is divided into the Target Area, and the Switchyard(s). Thermal and vibrational stability are provided in the Switchyards and Target Bay. The Target Area Building is a clean area.

The Target Area Building provides secondary confinement of the ionizing radiation and emissions which are produced by some of the shots.

\subsection{Target Bay}

The Target Bay is housed within the Target Area Building and contains the Target Chamber. The walls and roof of the Target Bay (along with the Target Chamber) provide the primary confinement of prompt and residual radioactivity which are produced by some of the shots. The room also provides personnel access to the components within the room.

The Target Bay requires a thermally- and vibrationally-stable and clean environment.

Because of the potential for air activation during high-yield experiments, the Target Bay HVAC system will be isolated and will generate a negative pressure in the Target Bay prior to and after high yield shots to confine activated air components and allow them to decay prior to release. The exhaust release point must be elevated above the highest point of the building.

The Target Bay is connected to a decontamination area which contains the Environmental Protection Systems which are used to process contaminated material and components.

Discharge water from fire suppression activity in the Target Bay must be collected for treatment and disposal. The Target Bay will serve as the collection reservoir. 


\subsection{Switchyards}

The Switchyards contain the mirrors used to route the laser beams to the appropriate ports in the walls of the Target Bay. They also include some of the laser and target diagnostics.

Many of the components in the Switchyards require a thermally- and vibrationally-stable environment.

The Switchyard (Target Area Building) walls and roof must be sufficiently thick to provide adequate shielding against prompt radiation.

The Switchyards are clean areas.

\subsection{Target Diagnostics Building}

The Target Diagnostics Building contains laboratory space for support of target diagnostics activities such as diagnostic assembly and calibration.

The building houses some of the target diagnostics and is capable of being modified to allow some future diagnostics.

The building also houses a target diagnostics data acquisition area which provides safeguard and security for up to and including SRD data

The basement of the building includes a decontamination area, a hot cell (where radiated components are temporarily stored to allow the radioactivity to decay immediately after extraction from the target chamber and prior to further processing and decontamination), and the Environmental Protection System. This system provides for processing and decontamination of components and effluents. It also includes the effluent monitors.

The Diagnostic Building includes the target receiving and installation area, which is where targets are delivered to the LTAB and processed for installation in the target chamber.

The building also includes staging areas for components and equipment.

The Diagnostic Building includes an elevator for personnel and equipment, a tank farm which includes liquid nitrogen and carbon dioxide and holding tanks for the Environmental Protection System effluents and waste water, and HVAC systems.

The basement of the building will be accessible by standard semi-tractor trailers,

\subsection{Environmental Control}

The laser, optics, and target have stringent stability requirements. To meet these requirements, the LTAB must provide precise temperature control and an extremely low level of vibration and acoustic noise.

\subsection{Clean Areas}

The following LTAB areas contain optics which require clean areas:

Laser Bay

Switchyards

Target Bay. 


\subsubsection{Optics Assembly Building}

The specific funtionalilty to be included in the Optic Assembly Building (OAB) is TBD.

For reference, the total anticipated NIF need for optic processing functionality is described in the following paragraphs. This description assumes that all this funtionalilty is included in the OAB. This assumption is presently being re-assessed, and the optimum distribution of the total functionality between the OAB and other support facilities is TBD.

The Optics Assembly Building will have adequate Class 100 cleanroom space to assemble the cavity mirrors, transport mirrors, polarizers, spatial filter lens assemblies, Pockels cells, amplifiers, final optics assemblies and interstage and beam transport systems. The Facility must have adequate capacity to clean the -600 parts/day required to meet the 24 month assembly schedule. Mechanical components will be cleaned to a level of less than .2 particles $/ \mathrm{cm}^{2}$ greater than 5 microns in size.

Mechanical components will progress from the receiving area, through the cleaning facility to the assembly area. Cleaned optics components will be transported from another facility to the optics assembly building loading dock, and then will progress from the receiving area directly into the assembly area. Cleaned, aligned optical assemblies will be transported to the LTAB for installation into the National Ignition Facility.

The major features of the facility are:

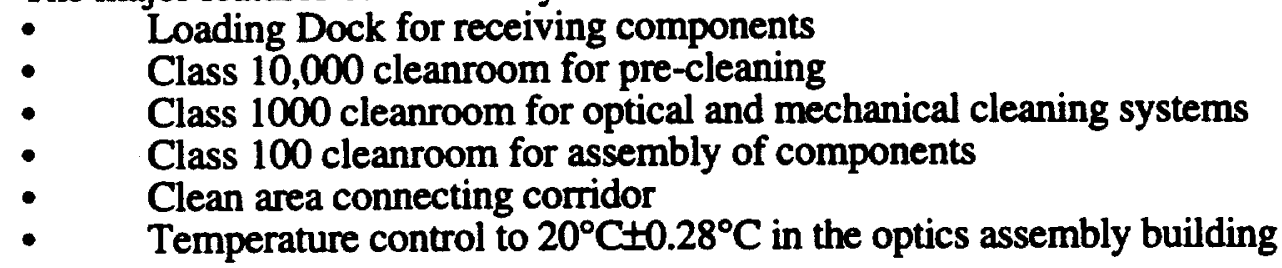

\subsubsection{Support Facilities}

Operation of the NIF will require support facilities including:

Office Building

Target Receiving and Inspection Building

General Assembly Building

Electro-Mechanical Shop

Warehouse (General Storage)

Shipping, Receiving and General Stores

Medical Facility

Cafeteria

Gas Station and Garage

Fire Station

Security and Badging

\subsubsection{Office Building}

The Office Building provides:

Offices for permanent technical staff and visiting scientists;

Conference rooms;

Library;

Computer facilities;

Drafting facilities; and

Physical Security including Limited-areas and Access Control. 


\subsubsection{Target Receiving and Inspection Building}

The Target Receiving and Inspection Building provides:

Clean areas and inspection laboratories for receiving and inspecting NIF targets;

Vibration-controlled environment;

Temperature- and humidity-controlled environment;

Cryogenic laboratories;

Central chemical waste system; and

Limited-area security controls.

This building will process up to (335) tritium targets annually.

\subsubsection{General Assembly Building}

The General Assembly Building will be used for assembly mechanical and electrical components. It will include:

Industrial-quality space,

Material handling equipment for large mechanical structures,

Assembly welding area, and

Local exhaust and ventilation systems.

\subsubsection{Electro-Mechanical Shop}

The Electro-Mechanical Shop will include:

Machine tools for fabricating components,

Electrical component fabrication and testing area, and

Local exhaust and ventilation systems.

\subsubsection{Warehouse (General Storage)}

The Warehouse will provide:

Bulk storage of NIF components, equipment and supplies,

Loading docks,

Fork Lift access,

Roll-up doors, and

Storage cabinets and shelving.

\subsubsection{Shipping, Receiving and General Stores}

The Shipping, Receiving and General Stores will be used for receival and shipment of materials, equipment and supplies.

It will provide:

Storage and distribution.

Loading docks.

Fork Lift access.

Large doors.

Storage cabinets and shelving. 


\subsubsection{Medical Facility}

The Medical Facility will provide the following:

Medical offices.

Emergency services.

Dispensary.

Decontamination.

Examination and therapy areas.

It shall be able to handle the following types of conditions:

radiation contamination,

basic life-support, and

minor injuries.

\subsubsection{Cafeteria}

An on-site cafeteria will provide food service, preparation and storage, for staff and visitors.

\subsubsection{Garage and Gas Station}

The Garage and Gas Station will support the NIF vehicles. It will include:

Garage for routine light maintenance and repair.

Refueling, and cleaning of plant vehicles and heavy equipment.

Gasoline, diesel.

\subsubsection{Fire Station}

An on-site fire station will provide primary response to NIF emergencies. The station will have:

Fire and emergency personnel and equipment.

Response capabilities for hazardous material incidents.

Emergency communications both on-site and to off-site agencies.

Living quarters for on-duty personnel and training facilities.

\subsubsection{Security and Badging}

The NIF site-security will be based in this building. It will be used for:

Site security administration.

Badging of personnel.

Site access control

\section{System Design Requirements}

This section contains the design requirements which shall be used for all of the NIF facilities conventional facilities. 


\subsection{Applicability to Site}

These requirements have been written for a generic site, such that NIF could be located at any of the five candidate sites with only minor modifications.

As a goal, the project should evaluate the conditions (enviromental, soil, etc.) at each of the candidate sites.

Where there is negligible cost increase, the design shall be compatible with as many of the potential sites as possible.

Where compatibility with more than one site results in a significant cost increase, the NIF conventional facilities may be designed for the preferred site (because it represents the most stressing seismic environment). Title II designs shall be for the specific site which is selected.

\subsubsection{Updating Requirements after Site Selection}

When a site selection is made, these requirements will be revised as necessary to include site-specific natural phenomena, environmental characteristics, and potential use of existing infrastructure, facilities, and services.

\subsection{Design Lifetime}

All new permanent construction for NIF shall be designed for at least a 30 year design life.

\subsubsection{Ease of Replacement}

Systems or portions of systems for which a 30 year design life is impractical shall be designed for ease of replacement, meaning replacement can be accomplished in a timely manner, at reasonable cost, and consistent with facility availability requirements. Replacement includes removal, refurbishment, and reinstallation of original equipment.

\subsubsection{Design Life of Existing Facilities}

The design life for the modification and use of existing facilities, or the use of existing facilities without modification, shall be evaluated on a case-by-case basis after final site selection.

\subsubsection{Facility Survival}

Because of its importance to the DOE, the NIF shall be designed to survive any abnormal event, including accidents and natural phenomena, expected to occur more frequently than once in 2000 years.

\subsubsection{Performance Class}

The LTAB shall be designed and constructed per performance class 2 (PC-2) as defined in DOE-STD-1020-94 (Natural Phenomena Hazards Design and Evaluation Criteria for DOE Facilities) and DOE-STD-1021-93.

Other facilities shall use a graded approach.

\subsubsection{Probability of Natural Phenomena}

The probabilities of occurrence listed in DOE-STD-1020-94 shall be utilized for natural phenomena. 


\subsubsection{Seismic Analysis}

Dynamic seismic analysis shall be performed on the primary structures (e.g., the Target Area Building, the Target Bay, and the Laser Building floor).

\subsection{Operations}

The National Ignition Facility shall be operated in a manner consistent with its role as a national resource.

\subsubsection{Personnel}

The NIF project shall provide a staffing plan.

Staffing shall be allocated to support all required operations, maintenance, and support functions.

The plan shall address construction, start-up activities, and operations.

The staffing plan shall be used to size personnel facilities such as office space, cafeteria, parking, etc.

\subsubsection{Operational Availability}

The facility shall be designed for maximum reasonable availability and rapid recovery from unplanned shutdowns.

\subsubsection{Reliability, Availability and Maintenance}

The components, systems, and processes that limit overall facility availability shall be identified during the design process through analyses of turnaround times, mean times between failures, mean times to repair, preventive maintenance requirements, etc.

\subsection{Reliability}

The facility shall have an overall reliability of $99.85 \%$. Reliability is defined as the probability of meeting the minimum requirements of the experiment per no-yield shot.

\subsection{Inherent Availability}

The facility shall have a shot availability of at least $99.15 \%$. The system is unavailable when it is undergoing unplanned maintenance. Unplanned maintenance includes failure detection and active repair as well as logistic and administrative downtimes.

\subsection{Spare Equipment}

Sufficient spares shall be maintained to satisfy the RAM specifications.

\subsection{Maintenance Equipment}

Suitable maintenance equipment shall be available as necessary to satisfy the RAM requirements.

\subsubsection{Maintainability}




\subsection{Maintenence Time Goal}

The facility shall have a scheduled maintenance plan that fits within an overall annual plant goal of 69 days. The unplanned maintenance goal is 2.3 days per year. Opportunistic maintenance activities are performed between shots and during other system downtimes.

\subsection{Maintainability Features}

The facility shall be designed to facilitate efficient maintenance. Surface finishes and coatings shall be selected with maintainability and cleanliness in mind. Features shall be incorporated in the facility to improve maintainability where they are shown to be cost-effective.

\subsubsection{Annual Shot Rate}

The facility shall be available for at least 770 no-yield target shots each year.

\subsubsection{Increased Shot Rate}

As a design goal, the facility should not preclude an increase in availability to 1200 total shots each year.

\subsubsection{Annual Number of Yield Shots}

The NIF shall be capable of performing up to 50 shots per year with a routine DT fusion yield of $20 \mathrm{MJ}$.

\subsubsection{Total Annual Yield and Source Team}

The NIF shall be capable of performing yield shots with total DT fusion yield of $1200 \mathrm{MJ} /$ year or $4.3 \mathrm{x}$ $10^{20}$ neutrons/year. For DT fuel, the monoenergetic neutron energy is $14.1 \mathrm{Mev}$. The contribution of D-D reactions to this source term can be ignored.

\subsubsection{Time Between No-yield Shots}

The facility shall be capable of maintaining a time between shots of 8 hour for shots with no fusion yield. The facility shall not preclude future upgrade to allow the conduct of experiments with a time between shots of 4 hours for shots with no fusion yield.

\subsubsection{Laser Shot Accuracy}

At least $80 \%$ of all laser shots shall meet all experimental requirement specifications (e.g., laser energy, beam balance, and pointing accuracy). 


\subsubsection{Recovery from Abnormal Events}

The time required for the Conventional Facilites to recover from any abnormal event shall be less than the maximum times cited below, as a function of the expected yearly frequency of occurrence of the event.

\begin{tabular}{cc} 
Expected Frequency of Occurrence Per Year. $F$ & Maximum Recovery Time \\
\hline$F \geq 1$ & 24 hours \\
$1>F>1 E-2$ & 1 week \\
$1 E-2>F \geq 5 E-4$ & 3 months
\end{tabular}

Probabilities listed in DOE-STD-1020-94 shall be used for natural phenomena.

For frequent events, the maximum allowed recovery time may be restricted by availability requirements to be less than that shown in the table above.

\subsubsection{Classified Operations}

The facility shall be designed to allow both classified (at the SRD level) and unclassified experiments.

\subsubsection{Changing Between Classification Levels}

The facility should allow changing classification levels with minimal impact on operations and cost.

\subsubsection{Safeguards and Security}

The NIF safeguards and security features shall meet the requirements of DOE Order 5632.1C, Protection of Safeguards and Security Interests, and DOE Order 470.1, Safeguards and Security Program. These requirements include physical protection of classified data and equipment and items in use and in storage.

\subsection{Establishment of Security Requirements}

For the facility security areas and access control, requirements shall be established based on the nature of experiments (i.e., classified or unclassified) being performed.

\subsection{Security - Limited Areas}

Limited areas will be defined in the NIF Security Procedures.

\subsection{Automated Data Processing Security}

Automated Data Processing (ADP) systems handling classified information shall meet the requirements of DOE Orders 5637.1, Classified Computer Security Program, and 5300.4D, Telecommunications: Protected Distribution Systems.

\subsection{Security Plan}

The NIF conventional facilities will comply with the NIF Security Procedures.

\subsection{Protection of Property and Facilities}

The NIF complex shall meet the requirements for physical protection of DOE property and unclassified facilities. 


\subsection{Environmental Protection and Health Safety}

The following orders, notices, and regulations summarize the Environmental Safety and Health requirements for the NIF Conventional Facilities:

151.1

420.1

440.1

N 441.1

P 450.1

451.1

5400.1

5400.5

$5820.2 \mathrm{~A}$

10 CFR 20

40 CFR $61(\mathrm{H})$

40 CFR 125

40 CFR 260-262

29 CFR 1910

29 CFR 1926

15 USC 2601-2692

33 USC 1251 et seq.

40 USC 6901-6992

42 USC 4321 et seq.

42 USC 7401
Emergency Management System

Facility Safety

Worker Protection for DOE Federal and Contractor Employees

Radiological Protection for DOE Activities

Environment, Safety, and Health Policy for the DOE Complex

National Environmental Policy Act Compliance Program

General Environmental Protection Program

Radiation Protection of the Public and the Environment

Radioactive Waste Management

Standards for Protection Against Radiation

National Emission Standard for Emissions of Radionuclides Other Than Radon from DOE Facilities

Criteria and Standards for National Pollutant Discharge Elimination System

Hazardous Waste Management System

OSHA - Operation

OSHA - Construction

Toxic Substance Control Act

Clean Water Act

Resource Conservation and Recovery Act

National Environmental Policy Act

Clean Air Act

\subsubsection{Siting}

Siting shall consider the effects of construction and operation on surrounding ecosystems and environmentally sensitive areas.

\subsubsection{2: Waste and Effluents}

The NIF shall minimize the generation of wastes at the source per:

DOE Policy P450.1, Environmental Safety and Health Policy for the Department of Energy Complex, General Environmental Protection Program, and

DOE Order 5820.2A, Radioactive Waste Management; and the Resource Conservation and Recovery Act (USC 6901 to 6992); and

the Toxic Substances Control Act (USC 2601-2692). 


\subsubsection{Liquid Effluents}

Liquid effluent discharges from NIF discharge points shall be monitored and controlled in compliance with

10 CFR 835,

DOE Order 5400.5, Radiation Protection of the Public and the Environment;

the Clean Water Act (33 U.S.C. 1251 et seq.); and

by conditions on 40 CFR 125 Criteria and Standards for National Pollutant Discharge Elimination System.

\subsection{Target Bay Liquid Effluents}

Any discharge water within the Target Bay that is potentially contaminated with radioactive substances shall be held until it is tested and confirmed to meet sewerable discharge requirements. This requirement includes water from fire-suppression activity within the Target Bay.

\subsubsection{Airborne Effluents}

Air emissions shall meet the requirements of

Section 3.1 (radiation shielding and confinement) for radionuclides and the requirements of the Clean Air Act, (42 U.S.C. 7401) including National Emission Standards for Hazardous Air Pollutants

(NESHAP), and state and local air quality management district requirements.

\subsection{Elevated Exhaust Release Point}

The final exhaust release point for the Environmental Protection Systems and any airborne radiological emissions should be elevated above the highest point of the facility for dispersion.

\subsection{Monitoring of Exhaust Air}

Exhaust air shall be continuously monitored for radioactivity.

\subsubsection{Radiation Protection}

Radiation protection shall include: shielding, control of workplace ventilation, monitoring of personnel for external and internal radiation dose, establishment of a routine contamination monitoring program including air monitoring, and the proper containment of radiation and radioactive materials.

\subsubsection{Maximum Credible Yield}

The maximum credible DT fusion yield produced by a single shot is $45 \mathrm{MJ}$, corresponding to $1.6 \times 10^{19}$ neutrons.

\subsection{Waste Handling Area Confinement and Ventilation}

The NIF waste handling areas shall comply with the standards of confinement and ventilation requirements specified by DOE Order 5820.2A, Radioactive Waste Management. 


\subsection{Waste Collection and Processing}

The NIF facilities shall be compatible with the operations and equipment required for collection, labeling, packaging, sorting, and shipment of hazardous waste, low-level radioactive waste (LLW), and mixed (LLW and hazardous) waste in accordance with the Resource Conservation Recovery Act and the following regulations: hazardous waste per 40 CFR 260, 261 and 262; low-level waste per DOE Order 5820.2A; and mixed (LLW and hazardous) waste per DOE Order 5820.2A, and 40 CFR 260.

\subsection{Negative Pressure Ventilation}

The ventilation system for the Switchyards and Target Bay shall operate at negative pressures during and immediately after shots of greater than one megajoule and provide secondary tritium confinement.

\subsubsection{Radiation Protection of the Public}

Collective and individual ionizing radiation doses to the public from all exposure pathways from the NIF shall meet the requirements of DOE Order 5400.5, Radiation Protection of the Public and the Environment, and 40 CFR 61, National Emission Standards for Emissions of Radionuclides Other Than Radon from Department of Energy Facilities.

\subsection{Public Exposure to Airborne Radionuclides}

Exposure of members of the public from emissions of radionuclides in the ambient air from normal NIF operations shall remain below $10 \mathrm{mrem} / \mathrm{y}$.

\subsection{Public Exposure from all Sources}

The facility shall meet the requirements of DOE Order 5400.5 [ICRP 60 \$40 (1990 Recommendations of the International Commission on Radiological Protection), 10 CFR 20.1301.a.1 (Code of Federal Regulations-Standards for Protection Against Radiation)] to not cause the public dose limit from all exposure modes and all sources of NIF radiation at the site boundary to exceed $100 \mathrm{mrem} / \mathrm{y}$.

\subsubsection{Radiation Protection of NIF Personnel}

The NIF personnel radiation protection program shall follow DOE Notice 441.1 Protection for Radiological Activities, and 10 CFR 835, Occupational Radiation Protection.

\subsubsection{ALARA Principle}

The ALARA (as low as reasonably achievable) principle shall be utilized in both design and operation of the facility to eliminate unnecessary radiation dose to workers, collected employees, and visitors from both routine and off-normal operations.

\subsubsection{Radiation Shielding}

The target bay shall be the primary barrier for prompt radiation, air activation, and residual radioactivity.

The radiation shielding design shall be more conservative than required by DOE Order 420.1, Facility Safety. As a design goal, the maximum dose to an individual worker shall be limited to one- tenth of the occupational external dose limits specified in 10 CFR 835.

\subsection{Concrete Shielding}

Concrete shielding shall comply with ACI 301, which provides adequate strength for DBE loads. 


\subsubsection{Radiation Monitoring of Switchyards, Target Bay and Target Chamber}

The Switchyards, Target Bay, and Target Chamber shall be monitored to ensure that radiological conditions are safe for personnel entry.

\subsubsection{Tritium Confinement}

The primary confinement of Tritium will be within the Target Experimental System. The Target Bay and decontamination room shall provide secondary confinement for potential leaks from the primary boundary.

\subsubsection{Compliance with Radiological Safety Requirements}

The requirements for radiological safety in DOE Order 420.1 , Facility Safety, should be evaluated by the designers and incorporated when they are determined to be cost effective, even though the projected inventory of tritium in NIF $(-0.05 \mathrm{~g}$ or $500 \mathrm{Ci})$ is well below the threshold for a nuclear facility.

\subsubsection{Decontamination and Decommissioning}

The NIF shall meet the requirements of DOE Order 420.1 (Facility Safety) and site-specific requirements for decontamination and decommissioning.

Conventional Facilities shall comply with the NIF Decontamination and Decommissioning (D\&D) Plan.

\subsubsection{Target Chamber Cleaning}

The NIF facilities shall be compatible with the equipment and operations required to meet the Target Chamber tritium level specifications.

\subsection{Target chamber interior decontamination}

The facility shall support personnel access to the inside of the target chamber for periodic cleaning necessary to maintain radiological, low-hazard, non-nuclear operations and for inspection and maintenance.

\subsubsection{Design for Decommissioning}

Facilities in which radioactive or other hazardous materials are utilized shall be designed to simplify decontamination and decommissioning and/or increase the potential for reuse. Features and procedures that simplify and facilitate decommissioning shall be identified during the planning and design phase based upon a proposed decommissioning method or conversion to other use.

\subsubsection{General Safety}

\subsubsection{Low-Hazard Radiological Facility}

The NIF shall be designed, constructed, and operated as a radiological low-hazard, non-nuclear facility. 


\subsubsection{Life Safety}

The NIF shall comply with the requirements for life safety contained in DOE Order 420.1 (Facility Safety).

The code shall be used to establish minimum requirements for life safety such as protection of vertical openings, travel distances, and capacities of means of emergency egress.

\subsection{Egress Features}

Particular focus shall be directed towards features related to the means of egress, such as protection of vertical openings, travel distances, capacities, and emergency lighting.

\subsection{Laser Safety}

The laser safety program shall comply with ANSI Z136.1, Laser Safety, and OSHA requirements. Exposure to hazardous levels of laser light shall be prevented by the use of physical barriers, interlocks, and personnel entry controls in addition to personnel training.

\subsection{Industrial Hygiene and Occupational Safety}

Industrial hygiene and occupational safety shall comply with 29 CFR 1910 and DOE Order 440.1, Worker Protection Management for DOE Federal and Contractor Employees.

\subsection{Construction Safety}

Construction safety shall comply with the requirements of 29 CFR 1926, OSHA and DOE Order 440.1, Worker Protection Management for DOE Federal and Contractor Employees.

\subsection{Default to Safe State Upon Loss of Power}

Facility subsystems (e.g., capacitor banks, vacuum systems, tritium recovery, nitrogen supply, and personnel safety interlock systems) shall be designed to default to a safe state upon loss of power.

\subsection{Facility Safety Interlocks}

The facility shall incorporate features, including safety interlocks, to restrict personnel access to all hazards.

Interlocks shall comply with Supplement 33.48 of the LLNL Health and Safety Manual.

Interlocks shall be dedicated, designed to fail safe and shall activate laser shutters and shut off power to laser systems if access control is violated.

\subsubsection{Fire Protection Program}

The NIF shall meet the design and fire protection requirements of DOE Order 420.1, Facility Safety, and the Uniform Building Code (UBC).

The requirements of the DOE fire protection program shall be documented and incorporated in the plans and specifications for all new facilities and for significant modifications of existing facilities. This includes a documented review by a qualified fire protection engineer of plans, specifications, procedures, and acceptance tests. 


\subsection{Fire Protection - Structural Members}

The structural members of the LTAB (including exterior walls, interior bearing walls, columns, floors, roofs, and supporting elements) shall, as a minimum, meet UBC fire-resistive standards.

\subsection{Fire Barriers}

Appropriate fire barriers shall be provided to limit property damage, fire propagation, and loss of life by separating adjoining structures, isolating hazardous areas, and protecting egress paths.

\subsection{Improved Risk Fire Protection}

The NIF shall meet the requirements for an "improved risk" level of fire protection sufficient to attain DOE objectives.

\subsection{Automatic Fire Sprinklers}

To achieve an "improved risk" level of protection, automatic fire sprinklers shall be installed throughout the complex.

\subsection{Ancillary Fire-Protection Systems}

The automatic fire sprinklers shall be coupled with adequate fire protection water supplies and automatic and manual means for detecting and reporting incipient fires.

\subsection{Fire Loss (Maximum Allowable)}

The maximum possible fire loss (MPFL) shall not exceed $\$ 150$ million per fire. When the MPFL exceeds $\$ 150 \mathrm{M}$, a redundant fire protection system and three-hour fire barriers are required to limit the maximum possible fire loss to $\$ 150 \mathrm{M}$.

\subsection{Fire Loss (Maximum Credible)}

The maximum credible fire loss shall not exceed $\$ 50$ million. When the possible fire loss exceeds $\$ 50$ $M$, a redundant fire protection system shall be provided that, despite the failure of the fire protection system, will limit the loss to $\$ 50 \mathrm{M}$.

\subsection{Electrical Power}

Electric power shall be installed in accordance with NFPA 70, which includes details from the National Electrical Code; IEEE 493, Recommended Practices for Design of Reliable Industrial and Commercial Power Systems; and ANSI C2, the National Electrical Safety Code.

\subsubsection{Voltage Quality}

Voltage shall be maintained in compliance with ANSI C84.1, Electrical Power Systems and Equipment-Voltage Rating $(60 \mathrm{HZ})$. Electrical supply systems shall operate within the limits specified for Range A of this specification. Voltage occurrences outside these limits should not exceed the Range $B$ limits. These variances should be limited in extent, frequency, and duration.

\subsubsection{Low Voltage Protection of Computers}

Computers shall be protected with low voltage dropouts requiring manual restart. 


\subsubsection{Standby Power}

Standby power shall be available for health, life, property, and safeguards and security loads, including emergency egress lighting, fire alarms and sensors, security systems, and radiation monitors.

\subsubsection{Power for Safety and Security Functions}

Power for safety and security functions shall be installed and operated according to NFPA 101, the Life Safety Code; ANSINFPA 110-1993, the Standard for Emergency and Standby Power Systems; NFPA 72, National Fire Alarm Code; and other applicable NFPA and OSHA standards.

\subsubsection{Standby Power for Operations}

Standby power shall be available to preserve process continuity in cases designated by the NIF Project and specified in the System Design Requirements. Neither uninterruptible power systems nor standby power is required for the computer systems.

\subsection{Future Modifications and Upgrades}

\subsubsection{Design and Construction Tradeoffs}

Where alternative designs and modes of construction are possible at essentially equivalent cost, the design and construction method that most readily allows for future reconfiguration and modification should be selected.

\subsubsection{Accommodating Range of Needs}

Whenever possible, the design should accommodate the requirements of users with diverse needs.

\subsubsection{Potential Upgrade to Direct-drive}

Future upgrade to allow direct-drive experiments, shall not be precluded in the baseline NIF design. In order to not preclude this option, the Facility System, in concert with other NIF systems, shall provide a conceptual design for the required beam transport to the target chamber and ensure that this transport can be accomplished by rearranging existing direct-drive components or adding additional components.

\subsubsection{Radiation Effects Testing Capability}

The NIF should provide the basic capability so as not to preclude radiation effects testing by DNA or DOE, with future upgrade. The design shall not preclude laser irradiation of distributed target arrays with future upgrade.

\subsubsection{Future Additional Target Chamber}

The design of the Facility shall not preclude the future installation of an additional target chamber, employing all laser beams, for weapons physics and/or radiation effects testing. As a part of the NIF project, the Facilities, in concert with other NIF systems, shall provide a general arrangement layout for the addition of the target chamber. All Facility designs shall be compatible with this design concept. All structual elements shall provide clearance for the identified future laser beam paths. Certain structures, such as building skins or shielding walls, require integrity to fulfill their functions prior to addition of the future target chamber; clearance for future beams is not required through such structures. However, their design shall be adequate that they will meet their requirements after addition of the future target chamber and associated beam clearances. 


\subsection{General Design Criteria}

DOE Order $6430.1 \mathrm{~A}$ shall be used for general facility design guidelines, where applicable, and where other requirements of this document do not list other requirements.

\subsection{Documentation}

The Conventional Facilities shall provide the following documents:

Energy Conservation Plan

Conventional Facilities Quality Plan

The following documents are required by the Conventional Facilities:

DOE 1324.5B Records Management Program

Operational Emergency Base Plan DOE 151.1

Quantitative Hazards Assessment DOE 151.1

Emergency Plan

DOE 151.1

Fire Hazards Analysis

Programmatic Environmental Impact Statement

Preliminary Safety Analysis Report

Quality Assurance Plan

Decontamination and Decommissioning Plan

\subsection{Quality Assurance Program}

The NIF conventional facilities, including design and construction activities, shall comply with the NIF Project Quality Assurance Program Plan.

\subsection{Experimental Facilities}




\subsubsection{Laser and Target Area Building}

The LTAB shall provide an optically-stable and clean environment to allow the system to routinely deliver high power laser beams to a target chamber.

The building shall provide for the following:

house the laser system;

house the target area;

house the control rooms;

house the diagnostics area;

provide space and equipment for related operations support including:

Mechanical, electronic and laser maintenance areas;

provide environmental control for the interior including:

precise temperature control,

controlled humidity,

clean areas,

low vibration;

provide environmental protection and safety including:

containment and monitoring of radiation,

decontamination facilities,

hazardous waste processing facilities, control of all emissions;

provide physical and technical security;

provide all other necessary services and utilities including: telecommunications systems, electrical utilities;

provide for visitors.

The LTAB is comprised of a Laser Building, a Target Area Building, and a Diagnostics Building.

The LTAB shall allow the lasers in the Laser Building to enter the Target Area Building and the Target

Chamber.

The Target Area Building shall be shielded for confinement of radioactivity.

\subsubsection{Laser Building}

Capable of housing the Laser Building and some of the ancillary subsystems.

\subsection{Laser Bays}

Capable of housing the Laser Assemblies and some of the transmission lines from the capacitor Bays.

\subsection{Capacitor Banks}

Capable of providing for capacitors that provide power to the laser amplifiers. 


\subsection{Operations Support Area}

The Operations Support Area shall include:

Control Room

Classified Control and Data Room

Master Oscillator Room

Operations Planning Room

Computer Room

LTAB Offices

Document Library

Conference Room

Security System Area

Technical Maintenance Areas

Restrooms

Custodial Room

\subsubsection{Target Area Building}

The target area shall be capable of accommodating diagnostic instruments for the measurements necessary for fusion ignition and applications experiments.

\subsubsection{A Diagnostic Removal and Replacement}

The facility shall be compatible with the equipment necessary to rapidly remove and replace diagnostics.

\subsection{Target Bay}

This shall be capable of housing the target chamber, final optics, vacuum piping, and target diagnostics while providing adequate shielding.

\subsection{Target Bay Cryogenics}

The target area support systems shall be capable of target operations with both cryogenic and non cryogenic targets containing fusion fuel.

\subsection{01. User-supplied Cryostats}

Provisions shall be made to accommodate and support experimenter-supplied cryostats for cryogenic targets.

\subsection{Switchyards}

Switchyards shall be capable of accommodating beam tubes and turning mirrors.

\subsubsection{Diagnostics Building}

The building shall include staging areas for diagnostic and target handling components and equipment.

The basement of the building shall be accessible by standard semi-tractor trailers. 


\subsection{Diagnostics Operations and Support}

The Target Diagnostics Building shall provide laboratory space for support of target diagnostics activities such as diagnostic assembly and calibration.

The building shall accomodate target diagnostics as identified on drawing (TBD) and shall be capable of being modified to allow addition of the LANSA diagnostic in the future.

The building shall also provide a target diagnostics data acquisition area which provides safeguards and security for up to and including SRD data.

\subsection{Decontamination Area}

The building shall include a decontamination area and a hot cell (where radiated components may be temporarily stored to allow the radioactivity to decay immediately after extraction from the target chamber and prior to further processing and decontamination).

\subsection{Environmental Protection System}

The building shall house the Environmental Protection System for processing and decontamination of components and effluents.

\subsection{Target Receiving and Installation}

The Diagnostic Building shall include a target receiving and installation area, where targets may be delivered to the LTAB and processed for installation into the target chamber.

\subsection{Tank Farm}

The Diagnostics Building shall have an exterior Tank Farm which provides the necessary compressed gases.

The Tank Farm shall also have tanks to collect the liquid effluents from the Decontamination Area and Envrionmental Protection System.

\subsubsection{Environmental Control}

\subsection{Vibration and Acoustic Noise}

The LTAB will house vibration-sensitive special equipment. The structural design of the Laser Bays, Switchyards and Target Bay shall provide means to effectively isolate this equipment to control acoustic noise and vibration within specified displacement and rotation requirements.

Any component located within the laser bay or target building shall be included in assessments of vibration. 


\subsection{Specific LTAB Vibration Constraints}

The LTAB vibrations should be maintained below $1 \times 10^{-10} \mathrm{~g}^{2} / \mathrm{Hz}$ from 1 to $200 \mathrm{~Hz}$ at the surface of the foundation to which the critical structures mount.

\subsection{Foundation Decoupling}

The LTAB foundation (to which the vibration-critical special equipment mounts) shall be physically decoupled from the foundations which support the external skin of the building.

\subsection{Floor Deflection}

Laser Bay and Switchyard floor deflections are critical to maintaining laser alignment. The specifications for allowable deflections shall be provided in the applicable SSDR(s).

\subsection{Temperature and Humidity}

The Laser Building and Target Area Building interior temperature shall be tightly controlled. Any component located within the laser bay or target building shall be included in assessments of thermal loads.

The Laser Building and Target Area Building interior relative humidity shall be compatible with Laser and Target operations. Target handling areas may have more stringent requirements than apply to the laser and optics.

The Diagnostic Building interior temperature is not critical and shall be controlled per applicable energy conservation standards.

\subsection{ASpecific LTAB Temperature Constraints}

The Laser Bays, Switchyards, and Target Bay shall be maintained at a temperature of $20^{\circ} \mathrm{C} \pm 0.28^{\circ} \mathrm{C}$. The Master Oscillator Room shall be maintained at a temperature of (TBD).

\subsubsection{Clean Areas}

The following LTAB locations shall be clean areas:

Master Oscillator Room

Laser Bays

Switchyards

Target Bay

\subsubsection{A Specific LTAB Cleanliness Constraints}

Clean Area surfaces, finishes, and structures shall be compatible with Class 10,000 cleanliness requirements.

Clean Area HVAC shall be compatible with Class 100,000 cleanliness requirements. 


\subsubsection{Electrical Supply and Grounding Systems}

The LTAB electrical supply and grounding systems shall be compatible with the control and data acquisition requirements. The Facilities shall comply with the NIF Grounding Plan, NIF-LLNL-94-211, L-17346-1. All components in the Laser Bay shall be-isolated from those in the Target Bay and separately grounded.

\subsubsection{Mechanical Equipment}

The LTAB shall have elevators for transportation of personnel and equipment.

There shall be overhead cranes in each Laser Bay and the Target Bay.

\subsubsection{Visitor Facilities}

The LTAB shall include a Visitor Lobby and provide facilities for visitor viewing of a Laser Bay, a Switchyard, and the interior of the Target Bay.

\subsubsection{Optics Assembly Building (TBD)}

\subsubsection{Internal Environment}

The internal temperature shall be maintained at $20^{\circ} \mathrm{C} \pm 0.28^{\circ} \mathrm{C}$.

\subsubsection{Clean Rooms}

The Optics Assembly Building shall have adequate Class 100 cleanroom space for TBD operations. The pre-cleaning area shall be maintained as a Class 10,000 cleanroom; the room housing the automated cleaning systems shall be maintained as a Class 1000 cleanroom; the assembly area shall be a Class 100 cleanroom.

\subsection{Cleaning Methods}

Because of the negative environmental impact of chlorinated fluorocarbons (CFCs) and VOCs, the Facility shall use an aqueous cleaning system that is environmentally safe and minimizes hazardous waste generation.

\subsection{Support Facilities}

\subsubsection{Office Building}

(TBD)

\subsubsection{Target Receiving and Inspection Building}

The NIF shall be able to receive, inspect, and handle targets filled with fusion fuel. These targets include cryogenic and/or classified targets. The targets will be from on-site and off-site sources (e.g., General Atomics). The filled targets containing tritium will be transported in Department of Transportation-certified shipping containers. The facility shall be able to handle multiple-target shipments.

NIF shall be able to process sufficient targets to support up to TBD (335) yield shots per year. 


\subsubsection{General Assembly Building}

The NIF Site Requirements specifies that an industrial-type building of approximately $22,000 \mathrm{ft}^{2}$ will be used to assemble large and heavy mechanical and electrical components that do not require a clean room environment. The facility must have the capability to handle these large and heavy assemblies. There is also a requirement to include a provision for assembly welding.

\subsubsection{Electrical / Mechanical Shop}

NIF requires and area of approximately $12,000 \mathrm{ft}^{2}$ for electrical and mechanical support shops. This area will house the machine tools to be used for repairs, maintenance, and special fabrications required for daily operations fo the NIF laser and its auxilary systems.

\subsubsection{Warehouse}

Approximately $30,000 \mathrm{ft}^{2}$ of industrial-quality space will be required for bulk storage of NIF components, equipment, and supplies for NIF operations.

\subsubsection{Shipping, Receiving, and Central Stores}

The site shall be capable of shipping and receiving all components for the NIF as defined in SSDR's.

\subsubsection{Medical Facility}

This facility shall have the capacity to support all of the personnel at the NIF site. It shall have the capabilities outlined in section 2.03.03.07.

\subsubsection{Cafeteria}

Shall provide food service per section 2.03.03.08.

\subsubsection{Garage and Gas Station}

Shall be capable of providing services per section 2.03.03.09

\subsubsection{Fire station}

Shall be capable of providing services per section 2.03.03.10.

\subsubsection{Security and Badging}

Shall be capable of providing services per section 2.03.03.11.

\section{Applicable Documents}

This section lists DOE Orders, codes, and standards considered applicable on October 1, 1993. The applicable portions of these documents apply. Applicable LLNL standards are being considered contingent upon the decision of the final site selection. 


\subsection{Freezing of Orders}

It is recognized that updates and additions to DOE Orders, federal regulations, and consensus industry standards are outside of the control of the project team and are a frequent source of cost and schedule growth. These requirements are all frozen as of March 1, 1996.

\subsection{Compliance with DOE Orders and Federal Regulations}

The NIF shall be designed and constructed in full compliance with DOE Orders and federal regulations.

\subsubsection{Exceptions to DOE Orders}

Exceptions shall be limited to those cases where the project has formally requested and been granted either an exemption or a finding of equivalency by Headquarters.

\subsubsection{List of Applicable DOE Orders}

This section lists DOE Orders, codes, and standards considered applicable on March 1, 1996. The listing begins with DOE and other federal regulations (e.g., Resource Conservation and Recovery Act), followed by national consensus standards, and finally other documents which establish facility requirements. The applicable portions of these documents will apply.

DOE 151.1

DOE 420.1

DOE 430.1

DOE 440.1

DOE N 441.1

DOE P 450.1

DOE 451.1

DOE 460.1

DOE 470.1 -

DOE 471.1

DOE 471.2

DOE M 471.2-1

DOE 1360.2B

DOE 5300.4D

DOE 5400.1 (Chg. 1)

DOE 5400.5 (Chg. 2)

DOE 5632.1C

DOE M 5632.1C-1

DOE 5637.1

DOE M 5639.6A-1

DOE $5700.6 \mathrm{C}$

DOE 5480.19 (Chg. 1)

DOE 5820.2A

DOE 5481.1B (Chg. 1)
Emergency Management System

Facility Safety

Life Cycle Asset Management

Worker Protection Management for DOE Federal and Contractor Employees

Radiological Protection for DOE Activities

National Environmental Ploicy Act Compliance Program

Packaging and Transportation Safety

Safeguards and Security Program

Identification and Protection of Unclassified Controlled Nuclear Information $(9 / 25 / 95)$

Information Security Program

Manual for Classified Matter Protection and Control (9/26/95)

Unclassified Computer Security (5/18/92)

Telecommunications: Protected Distribution Systems (3/4/94)

General Environmental Protection Program (6/29/90)

Radiation Protection of the Public and Environment (1/7/93)

Protection and Control of Safeguards and Security Interests (7/15/94)

Manual for Protection and Control of Safeguards and Security Interests

Classified Computer Security Program

Manual of Security Requirements for the Classified Automated Information System

Quality Assurance (8/21/91)

Conduct of Operations Requirements for DOE Facilities (5/18/92)

Radioactive Waste Management (9/26/88)

Safety Analysis and Review System (5/19/87)

Technical Surveillance Countermeasures Procedural Manual (classified) 


\subsubsection{Partial List of Applicable Federal Regulations}

10 CFR 435 Energy Conservation Voluntary Standards for Commercial and Multi-Family High

10 CFR 835

10 CFR 20

Risk Residential Buildings

- Standards for Protection Against Radiation

10 CFR 830.110 Nuclear Safety Management, Safety Analysis Report

28 CFR 36

Americans with Disabilities Act

29 CFR 1910

Code of Federal Regulations, Occupational Safety and Health Administration, Department of Labor

29 CFR 1910.7 Definitions and Requirements for a Nationally Recognized Testing Laboratory

40 CFR $61 \quad$ National Emissions Standards for Hazardous Air Pollutants (NESHAP)

40 CFR 121-130 Federal Water Pollution Control Act

40 CFR 260-272 Resource Conservation and Recovery Act (RCRA)

40 CFR 300-399 Comprehensive Environmental Response, Compensation \& Liability Act

40 CFR $1501 \quad$ National Environmental Policy Act (NEPA)

41 CFR 101-91.6 FPM Regulations, Architectural Barriers Act PL $90-480$

Fed-Std-209E Airborne Particulate Cleanliness Classes in Cleanrooms and Clean Zones

Fed-Std-975 Uniform Federal Accessibility Standards

33 USC 1251 Clean Water Act

Clean Air Act

USC 6901 et seq. Resource Conservation and Recovery Act

\subsection{Codes and Standards}

Nationally recognized codes, standards, and guides should be utilized whenever available. A partial listing of these documents and the applicable revisions is included in the following sections. Additional references may be identified and formally added during the Conceptual and Title I design phases, with the list baselined at the end of Title I design.

\subsubsection{Updating List of Codes and Standards}

Updates and additions to the baselined list codes and standards after the completion of Title I design shall be approved through the Project Change Control Process. 


\title{
4.03.02. List of Applicable National Consensus Codes and Standards
}

\author{
ACGIH Industrial Ventilation Manual
}

ACI 318

ANSI C2 National Electrical Safety Code

ANSI C84.1 Electric Power Systems and Equipment -- Voltage Rating $(60 \mathrm{~Hz})$

ANSI N13.1-1969Giude to Sampling Airbome Radioactive Materials in Nuclear Facilities

ANSI Z136.1 (Laser Safety)

ANSI Z358.1 Standard for Emergency Eyewashes and Showers

ASHRAE 62-1989Ventilation for Acceptable Indoor Air Quality

ICRP 60 S40 1990 Recommendations of the International Commission on Radiological Protection

IEEE 466

IEEE 493

NFPA 110

NFPA 101

Standard for Emergency and Standby Power Systems (The Orange Book)

Recommended Practices for Design of Reliable Industrial and Commercial Power Systems

NFPA 70

NFPA 72

OSHA

UBC

Emergency and Standby Power Systems

Life Safety Code

National Electrical Code

National Fire Alarm Code

(DOE 1300.2A)

(Construction Safety, Laser Safety, Standby Power)

(Fire Resistive Stds)

Uniform Plumbing Code

(1) All DOE facilities, programs, and projects shall use non-government standards (NGSs) in their design, construction, testing, modification, operation, decommissioning, decontamination, and remediation when such standards are adequate and appropriate for the intended application. If there is a conflict of requirements between the NGSs and the requirements or policy of the Department as established in Directives, Rules, Safety Guides, DOE standards, limited standards, or other Departmental policy documents such that the DOE requirements are more conservative or restrictive than the NGSs, then the DOE requirements shall be used;

(2) Use of any standard in the design, construction, testing, modification, operation, decommissioning, decontamination, and remediation of DOE facilities, programs, or projects shall be documented in appropriate design or safety documents for those activities, such as System Design Descriptions and Safety Analyses Reports;

(3) Standards should be referenced, in entirety or in part, tailored as appropriate to specific needs. Where parts of standards are referenced in contracts, specifications, or other documents, these documents may include the text from the standards provided that the text is quoted without change. When these documents contain modified requirements from standards, then the modification should be clearly identified. In all cases, the issue date of the standard used should be documented or the specific index of standards to be applied must be specified; 


\subsection{State and Local (County, City, etc.) Requirements} (site-specific)

\subsection{Applicable LLNL Standards}

(site-specific)

LLNL Metric Transition Path, Committee on Metrification, October 10, 1992.

Design Safety Standards -- Mechanical Engineering, Rev. 7, Feb. 1993, LM-012.

Health and Safety Manual, March 1989, M-010.

Plant Engineering Drafting Manual.

Facility Standards.

Hazards Control Manual, M010. (same as Health and Safety Manual above?)

Mechanical Engineering Design Practice, M-256.

Mechanical Engineering Policy Procedures Manual. 


\subsection{Applicable NIF Project Documents}

NIF Justification of Mission Need

NIF Draft Preliminary Environmental Impact Statement

National Ignition Facility Functional Requirements and Primary Criteria, Draft, 1/9/96 --

NIF-LLNL-96-011 (L-21166-01).

NIF Site Requirements, Rev. (TBD), (date) -- NIF-LLNL-93-089 (L-16883-1).

NIF Quality Assurance Plan, Rev. (tbd), (date) -- NIF-LLNL-93-044 (L-15959-1).

NIF Draft Preliminary Environmental Impact Statement.

NIF Staffing Plan

NIF Decontamination and Decommissioning Plan.

NIF Conceptual Design Report, May 1994 -- NIF-LLNL-94-113 (L-16973-1).

NIF System Design Requirements, Laser (SDR 002), Rev. 0, March 1994 -- NIF-LLNL-xx-xxx (L-xxxxx-x).

NIF System Design Requirements, Target Area (SDR 003), Rev. 0, March 1994 -- NIF-LLNL-xx-xxx (L-16983-1).

NIF System Design Requirements, Integrated Computer Controls (SDR 004), Rev. 0, March 1994 -NIF-LLNL-xx-xxx (L-xxxxx-x).

NIF System Design Requirements, Optics (SDR 005), Rev. 0, March 1994 -- NIF-LLNL-xx-xxx (L-xxxxx-x).

\subsection{Applicable NIF Drawings}

The following NIF Project drawings apply as specified in sections 3.2 to 3.6. The specified revision applies.

TBD [overall optical component layout]

TBD [facility footprint drawing] 


\section{Acronyms}

ACGIH American Congress of Government and Industrial Hygienists

ACI American Concrete Institute

ALARA As Low As Reasonably Achievable

ANSI American National Standards Institute

APE Associate Project Engineer

ASHRAE American Society of Heating, Refrigeration and Air Conditioning Engineers

CFC Chlorinated Fluorocarbon

CFR Code of Federal Regulations

D\&D Decontamination and Decommissioning

DOE Department of Energy

ES\&H Environmental Safety and Health

FHA Fire Hazards Analysis

FRPC Functional Requirements / Primary Criteria

HC Hazard Category

HVAC Heating, Ventilation and Air Conditioning

I\&C Instrumentation and Control

ICRP International Commission on Radiation Protection

IEEE Institute of Electronic and Electrical Engineers

LLNL Lawrence Livermore National Laboratory

LN Liquid Nitrogen

LNG Liquified Natural Gas

LTAB Laser and Target Area Building

MPFL Maximum Permissible Fire Loss

NFPA National Fire Protection Association

NIF National Ignition Facility

OAB Optics Assembly Building

OSHA Occupational Health and Safety Act

PC Performance Class

PEIS Preliminary Environmental Impact Statement

PHA Preliminary Hazards Analysis

RAM Reliability, Availability and Maintainability

SAR Safety Analysis Report

SDR System Design Requirement(s)

SRD Secret Restricted Data

SSDR Subsystem Design Requirement(s)

UBC Uniform Building Code

USC United States Code

VOC Volatile Organic Compound

WBS Work Breakdown Structure 


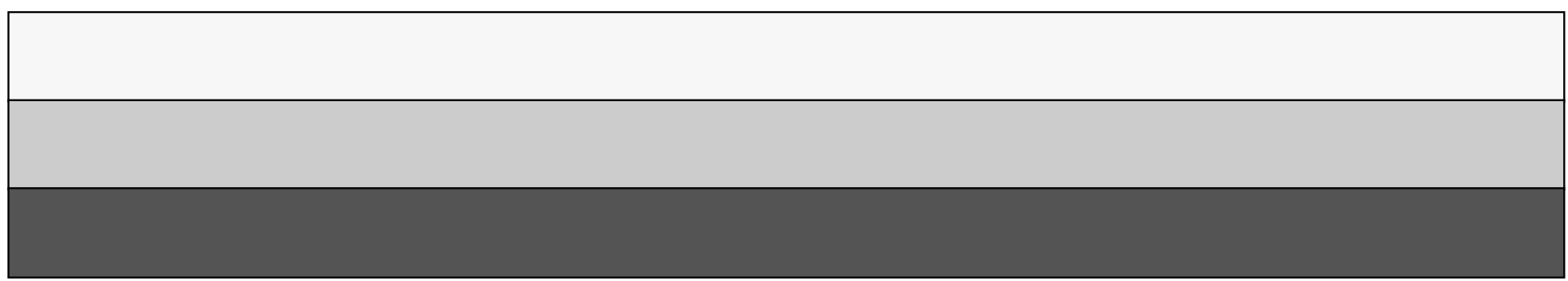

